\title{
PENGARUH KONSENTRASI SODA ABU TUNGKU KOPRA ASAP DAN ASAP CAIR TERHADAP KUALITAS MI BASAH
}

\author{
EFFECT OF SODA ASH FROM SMOKED COPRA AND LIQUID SMOKE \\ CONCENTRATION ON WET NOODLES' QUALITY
}

\author{
Shinta Wahyu Apriyani, Alim Mahawan Nuryadi, Yunita Filia Assah \\ Balai Riset dan Standardisasi Industri Manado \\ Jalan Diponegoro No. 21-23 Manado 95112 \\ Telp. (0431) 852395, Fax. (0431) 852396 \\ e-mail: fishinta21@gmail.com
}

\begin{abstract}
ABSTRAK
Mi merupakan makanan yang dibuat dari tepung terigu dan dikonsumsi secara luas di masyarakat karena harganya yang murah dan pembuatannya mudah. Mi basah mempunyai kadar air tinggi sehingga tidak dapat disimpan lama. Hal ini menjadikan banyak pihak berlaku curang dengan cara menambahkan bahan makanan non pangan seperti boraks atau formalin untuk mendapatkan mi basah yang kenyal dan memperpanjang masa simpan. Pada penelitian ini, digunakan soda abu tungku kopra asap sebagai bahan pengenyal dan asap cair sebagai bahan pengawet mi basah. Penelitian pertama adalah penambahan larutan soda abu ke dalam adonan mi dengan perlakuan $0,2,3,4,5$ dan $10^{\circ}$ Baume untuk kemudian dilanjutkan dengan uji kesukaan. Penambahan soda abu $4^{\circ}$ Baume menghasilkan mi basah yang paling disukai. Penelitian dilanjutkan dengan perlakuan penambahan asap cair sebanyak $0 \%(A), 0,5 \%(B), 1 \%$ (C), $1,5 \%$ (D) dan $2 \%$ (E). Mi basah yang dihasilkan kemudian diuji kadar protein, kadar abu dan kadar airnya serta uji organoleptik dan cemaran mikrobiologinya selama penyimpanan (hari ke-1, ke-7, ke-14 dan ke-21). Dari hasil pengamatan didapat kadar protein berkisar antara $6,18-7,72 \%$, kadar abu 1,041,36\% dan kadar air 50,60-55,64\%. Dari pengamatan fisik, sampai penyimpanan hari ke-21, mi basah masih kenyal dan tidak tumbuh jamur yang terlihat. Pada hari ke-21 jumlah ALT berkisar antara $1,59 \times 10^{1}$ $1,09 \times 10^{2}$ cfu, sedangkan jumlah kapang berkisar antara $7,72 \times 10^{0}-2,55 \times 10^{1} \mathrm{cfu}$, masih lebih kecil dari persyaratan SNI (2406-90) yaitu $1,0 \times 10^{6}$ dan $1,0 \times 10^{4} \mathrm{cfu}$. Dapat disimpulkan bahwa penambahan soda abu dan asap cair dapat menghasilkan mi basah yang kenyal dan memiliki daya simpan lama.
\end{abstract}

Kata kunci: Asap cair, mi basah, soda abu.

\section{ABSTRACT}

Noodle is a food made from wheat flour and widely consumed because of its low price and easy to manufacture. Wet noodles have high water content so they cannot be stored for long. This characteristic leads to some improper production of wet noodles by adding non-food ingredients such as borax or formalin to get chewy wet noodles and to extend the shelf life. In this study, soda ash from copra furnace and liquid smoke were added to wet noodles as texturizer and preservatives recpectively. The first study was the addition of soda ash solution into the noodle mixture with 0,2, 3, 4, 5 and $10^{\circ}$ Baume treatments then proceed with the preference test. The addition of $4^{\circ}$ Baume soda ash produces the most preferred wet noodles. The study continued with the treatment of adding liquid smoke as much as $0 \%(A), 0.5 \%(B), 1 \%$ $(C), 1.5 \%(D)$ and $2 \%(E)$. The wet noodles produced were then analyzed for protein, ash and moisture content as well as organoleptic and microbiological contamination tests during storage $\left(1^{\text {st }}, 7^{\text {th }}\right.$, $14^{\text {th }}$ and $21^{\text {st }}$ days). From the results of the observation, it was found that protein levels ranged from 6.18 to $7.72 \%$, ash content from 1.04 to $1.36 \%$ and water content from 50.60 to $55.64 \%$. From physical observation, until the $21^{\text {st }}$ day storage, wet noodles are still springy and no visible fungus grows. On the $21^{\text {st }}$ day the number of $A L T$ ranges from $1.59 \times 10^{1}-1.09 \times 10^{2} \mathrm{cfu}$, while the number of molds ranges from $7.72 \times 10^{0}-2.55 \times 10^{1} \mathrm{cfu}$, fewer than maximum number permitted by SNI requirements $(2406-90)$ ie $1.0 \times 10^{6}$ and $1.0 \times 10^{4} \mathrm{cfu}$. It can be concluded that the addition of soda ash and liquid smoke can produce wet noodles that are chewy and have a long shelf life.

Keywords: Liquid smoke, soda ash, wet noodles.

\section{PENDAHULUAN}

Soda abu adalah istilah yang mengacu pada senyawa-senyawa natrium seperti soda kaustik $(\mathrm{NaOH})$, abu soda
$\left(\mathrm{Na}_{2} \mathrm{CO}_{3}\right)$, soda kue $\left(\mathrm{NaHCO}_{3}\right)$, air soda (larutan encer $\mathrm{Na}_{2} \mathrm{Co}_{3}$ yang dijenuhi $\mathrm{CO}_{2}$ untuk campuran berbagai minuman). Soda abu atau abu soda $\left(\mathrm{Na}_{2} \mathrm{CO}_{3}\right)$ adalah suatu 
kristal yang berwarna putih yang larut dalam air dan hidroskopis. Soda abu bila dilarutkan dalam air akan membentuk sifat basa. Soda abu ini berfungsi sebagai humektan, yaitu bahan makanan tambahan yang dapat menyerap kelembapan sehingga dapat mempertahankan kadar air dalam makanan. Di samping itu juga, soda abu berfungsi sebagai pengemulsi dan pemantap di mana bahan tambahan ini dapat membantu terbentuknya atau memantapkan system disperse pada makanan.

Soda abu sebagai pemantap makanan dapat dibuat dari tanaman tertentu seperti kulit kapuk ${ }^{(1,2)}$, tempurung ${ }^{(3)}$ dan sabut kelapa ${ }^{(4)}$, merang ${ }^{(5)}$ dan lain-lain. Bagian tanaman tersebut jika dibakar sempurna akan dihasilkan soda abu. Soda abu yang berasal dari sabut kelapa mempunyai komposisi sebagai berikut: kadar soda abu $39,36 \%$, soda bikarbonat 6,08\%, Kalium ( $\left.\mathrm{K}_{2} \mathrm{O}\right) \quad 52,44 \%$, Natrium $\left(\mathrm{Na}_{2} \mathrm{O}\right) 7,47 \%{ }^{(6)}$. Secara tradisional, abu pembakaran sabut kelapa digunakan sebagai bahan tambahan makanan pada proses pembuatan mi basah.

Mi basah adalah mi segar yang telah direbus dan biasanya diberi sedikit minyak untuk mencegah supaya mi tidak saling melekat serta telah mengalami proses perebusan setelah tahap pemotongan dan sebelum dipasarkan. Kadar airnya dapat mencapai $52 \%$ sehingga daya tahan simpannya relatif singkat (40 jam pada suhu kamar) ${ }^{(7)}$. Mi basah yang hasil penelitian dengan penambahan soda abu dari pembakaran sabut kelapa akan rusak jika disimpan di suhu ruang selama 48 jam $^{(6)}$. Hal ini dikarenakan soda abu yang ditambahkan hanya berfungsi sebagai pengenyal dan bukan sebagai bahan pengawet. Bahan pengawet $\mathrm{mi}$ basah perlu ditambahkan jika ingin memperpanjang masa simpan mi basah.

Asap cair merupakan hasil destilasi atau pengembunan uap hasil pembakaran langsung dan tidak langsung dari bahanbahan yang banyak mengandung karbon serta senyawa-senyawa lain. Asap memiliki kemampuan untuk mengawetkan bahan makanan karena destilasi asap atau asap cair tempurung mengandung lebih dari 400 komponen dan memiliki fungsi sebagai penghambat perkembangan bakteri dan relatif aman sebagai pengawet alami antara lain asam, folat dan karbonil ${ }^{(8)}$.

Penggunaan bahan tambahan pangan (BTP) dalam produk pangan yang tidak mempunyai risiko kesehatan dapat dibenarkan karena hal tersebut lazim digunakan. Penambahan BTP secara umum bertujuan untuk (1) meningkatkan nilai gizi makanan, (2) memperbaiki nilai sensori makanan, dan (3) memperpanjang umur simpan (shelf life) makanan.

Penelitian ini dilakukan untuk mengetahui pengaruh penggunaan soda abu dari sabut kelapa terhadap rasa, warna dan tekstur mi basah. Serta mengetahui pengaruh soda abu sabut kelapa dan asap cair tempurung kelapa terhadap lama simpan mi basah.

\section{BAHAN DAN METODE}

\section{Bahan Penelitian}

Bahan-bahan yang digunakan dalam penelitian ini adalah tepung terigu, tepung tapioka, telur, soda abu, garam, air, minyak goreng, asap cair, kemasan dan bahanbahan untuk analisis laboratorium. 


\section{Peralatan Penelitian}

Alat-alat yang digunakan terdiri dari mixer, alat cetak mi, panci stainless steel, loyang plastik, saringan, sendok, pengaduk, timbangan, kompor, gelas ukur, grinder dan peralatan untuk analisis laboratorium.

\section{Metode Penelitian}

Untuk mengetahui pengaruh penggunaan soda abu dari sabut kelapa terhadap rasa, warna dan tekstur mi basah

- Tahapan pembuatan mi dengan perlakuan soda dari abu tungku kopra asap

Ditimbang tepung terigu sebanyak 1 $\mathrm{kg}$ dalam wadah. Siapkan larutan soda sesuai perlakuan yaitu $0,2,3,4,5$ dan $10^{\circ}$ Baume. Tambahkan garam $2 \%$ (b/b) ke dalam larutan soda yang telah diukur 'Baume sampai garam larut. Larutan soda dan garam dimasukkan ke dalam wadah yang berisi tepung terigu dan diaduk selama \pm 10 menit hingga halus dan kalis. Bentuk adonan hingga berbentuk elastis lalu diamkan selama 30 menit dan tutup dengan serbet. Masukkan adonan ke dalam penggiling (roller) hingga berbentuk lembaran tipis panjang dan dicetak berbentuk mi. Siapkan air yang telah mendidih, rebus mi \pm 5 menit dan ditiriskan dan tambahkan minyak goreng $30 \mathrm{gr}$ kemudian dinginkan dan kemas. Dilanjutkan uji kesukaan terhadap warna, rasa, tekstur dan bau. Mi basah yang paling disukai oleh panelis diteruskan ke tahap penelitian selanjutnya.

- Tahapan pembuatan mi yang diperlakukan dengan asap cair

Ditimbang tepung terigu sebanyak 1 $\mathrm{kg}$ dalam wadah. Siapkan larutan soda $4^{\circ}$ Baume lalu tambahkan garam $2 \%$ ke dalam larutan soda yang telah diukur $4^{\circ}$ Baume sampai garam larut. Larutan soda dan garam dimasukkan ke dalam wadah yang berisi tepung terigu dan diaduk selama \pm 10 menit hingga halus dan kalis. Bentuk adonan hingga elastis lalu diamkan selama 30 menit dan tutup dengan serbet. Masukkan adonan ke dalam penggiling (roller) hingga berbentuk lembaran tipis panjang dan dicetak berbentuk mi. Siapkan air yang telah ditambahkan asap cair sesuai perlakuan yaitu A (0\%); B (0,5\%); C (1\%); D (1,5\%); dan E (2\%) lalu didihkan. Rebus mi \pm 5 menit ke dalam air yang mengandung asap cair lalu ditiriskan dan tambahkan minyak goreng 30 gr kemudian dinginkan dan kemas. Mi basah dilanjutkan ke tahapan pengamatan.

- Tahapan pengamatan

Mi basah diamati secara organoleptik serta diuji kadar protein, kadar air dan kadar abunya. Mi basah disimpan di suhu dingin (refrigerator) untuk kemudian diamati pertumbuhan mikroba (Angka Lempeng Total) dan pertumbuhan kapang selama waktu penyimpanan. Pengamatan dilakukan pada hari ke-1, 7, 14 dan ke -21.

\section{HASIL DAN PEMBAHASAN}

\section{Uji Kesukaan}

Dari Tabel 1, dapat dilihat bahwa mi basah yang dibuat dengan penambahan soda abu sebesar $4^{\circ}$ Baume dirasa panelis mempunyai rasa, warna, tekstur dan bau yang paling disukai. Penambahan soda abu yang lebih besar dari $4^{\circ}$ Baume dilaporkan mempunyai rasa pahit yang tidak disukai panelis. Gugus karbonat dalam soda abu mempunyai sifat basa kuat yang ditandai dengan rasa pahit. Penambahan soda abu disarankan tidak 
melebihi $0,6 \%$ dari berat bahan untuk menghindari rasa pahit. Penambahan soda abu meningkatkan kesukaan panelis terhadap tekstur mi basah. Soda abu berfungsi untuk mempercepat pengikatan gluten, meningkatkan elastisitas dan fleksibilitas mi, meningkatkan kehalusan tekstur, dan meningkatkan kekenyalan $\mathrm{mi}^{(5)}$.

Tabel 1. Hasil pengamatan uji kesukaan (warna, rasa, tekstur, bau) sampel mi basah yang ditambahkan soda abu

\begin{tabular}{ccccc}
\hline $\begin{array}{c}\text { Perlakuan penambahan } \\
\text { soda abu ( }\end{array}$ & \multicolumn{3}{c}{ Skor } \\
\cline { 2 - 5 } & Warna & Rasa & Tekstur & Bau \\
\hline 0 & $3,03^{\mathrm{a}}$ & $3,78^{\mathrm{b}}$ & $3,03^{\mathrm{a}}$ & $3,53^{\mathrm{a}}$ \\
2 & $3,29^{\mathrm{a}}$ & $3,90^{\mathrm{bc}}$ & $3,18^{\mathrm{a}}$ & $3,56^{\mathrm{a}}$ \\
3 & $3,46^{\mathrm{a}}$ & $4,00^{\mathrm{bc}}$ & $3,59^{\mathrm{b}}$ & $3,65^{\mathrm{a}}$ \\
4 & $4,31^{\mathrm{b}}$ & $4,28^{\mathrm{c}}$ & $4,03^{\mathrm{c}}$ & $4,56^{\mathrm{b}}$ \\
5 & $4,34^{\mathrm{b}}$ & $3,81^{\mathrm{b}}$ & $4,01^{\mathrm{c}}$ & $4,53^{\mathrm{b}}$ \\
10 & $4,41^{\mathrm{b}}$ & $2,78^{\mathrm{a}}$ & $4,25^{\mathrm{c}}$ & $3,31^{\mathrm{a}}$ \\
\hline
\end{tabular}

Keterangan: 1=Sangat tidak suka; 2=Tidak suka; 3=Agak tidak suka; 4=Suka dan 5=Sangat suka

\section{Uji Organoleptik}

Pada Tabel 2 dapat dilihat bahwa penambahan soda abu dan asap cair tidak mempengaruhi warna mi basah yang dihasilkan. Mi basah yang dihasilkan berwarna kuning dan dapat diterima oleh panelis. Tekstur mi basah juga dinilai kenyal dan penambahan asap cair tidak mempengaruhi kekenyalan mi. Hal ini karena jumlah soda abu yang berfungsi membantu pembentukan gluten yang ditambahkan ke adonan mi tetap, yaitu sebanyak $4^{\circ}$ Baume.

Tabel 2. Hasil pengamatan organoleptik (warna, bau, tekstur dan pertumbuhan jamur) mi basah pada penyimpanan suhu $5^{\circ} \mathrm{C}$

\begin{tabular}{cccllll}
\hline Hari & Perlakuan & $\begin{array}{c}\text { Asap cair } \\
(\%)\end{array}$ & \multicolumn{1}{c}{ Warna } & \multicolumn{1}{c}{ Bau } & Tekstur & $\begin{array}{c}\text { Pertumbuhan } \\
\text { jamur }\end{array}$ \\
\hline 1 & A & 0,0 & Kuning & Bau normal mi & Kenyal & Tidak tumbuh \\
& B & 0,5 & Kuning & Asap cair & Kenyal & Tidak tumbuh \\
& C & 1,0 & Kuning & Asap cair & Kenyal & Tidak tumbuh \\
& D & 1,5 & Kuning & Asap cair kuat & Kenyal & Tidak tumbuh \\
7 & E & 2,0 & Kuning & Asap cair kuat & Kenyal & Tidak tumbuh \\
& A & 0,0 & Kuning muda & Bau normal mi & Kenyal & Tidak tumbuh \\
& B & 0,5 & Kuning & Asap cair & Kenyal & Tidak tumbuh \\
& C & 1,0 & Kuning & Asap cair & Kenyal & Tidak tumbuh \\
& D & 1,5 & Kuning & Asap cair & Kenyal & Tidak tumbuh \\
& E & 2,0 & Kuning & Asap cair & Kenyal & Tidak tumbuh \\
& A & 0,0 & Kuning & Bau normal mi & Kenyal & Tidak tumbuh \\
& B & 0,5 & Kuning & Asap cair & Kenyal & Tidak tumbuh \\
& C & 1,0 & Kuning & Asap cair & Kenyal & Tidak tumbuh \\
& D & 1,5 & Kuning & Asap cair & Kenyal & Tidak tumbuh \\
& E & 2,0 & Kuning & Asap cair & Kenyal & Tidak tumbuh \\
& A & 0,0 & Kuning & Bau normal mi & Kenyal & Tidak tumbuh \\
& B & 0,5 & Kuning & Asap cair & Kenyal & Tidak tumbuh \\
& C & 1,0 & Kuning & Asap cair & Kenyal & Tidak tumbuh \\
& D & 1,5 & Kuning & Asap cair & Kenyal & Tidak tumbuh \\
& E & 2,0 & Kuning & Asap cair & Kenyal & Tidak tumbuh \\
\hline
\end{tabular}

Keterangan: $A=$ direndam larutan asap cair $0,0 \% ; B=$ direndam larutan asap cair $0,5 \%$; $=$ direndam larutan asap cair 1,0\%; D=direndam larutan asap cair 1,5\%; $E=$ direndam larutan asap cair $2,0 \%$ 
Sampai pada hari ke-21, warna serta tekstur mi basah tidak mengalami kemunduran. Selain itu, sampai pada hari ke-21 mi basah yang diamati tidak menunjukkan adanya pertumbuhan jamur. Penambahan asap cair pada mi basah dapat terdeteksi oleh panelis melalui bau, bahkan pada persentase terkecil yaitu $0,5 \%$. Panelis membaui aroma asap cair yang kuat pada penambahan sebanyak 1,5 dan $2 \%$, namun aroma asap cair masih dapat diterima oleh panelis. Asap cair dari tempurung kelapa yang mempunyai keistimewaan utama dalam intensitas warna, bau, serta cita rasa spesifik $^{(9)}$.

Kadar Protein, Kadar Abu dan Kadar Air.

Pada Tabel 3 dapat dilihat kadar protein mi basah yang dihasilkan berkisar antara $6,18-7,72 \%$. Kadar protein yang rendah ini disebabkan karena pada pembuatan mi tidak ditambah dengan telur. Jumlah protein ini sudah memenuhi syarat SNI $(2987-2015)^{(10)}$ yaitu minimum $6 \%$. Kadar protein dapat ditingkatkan dengan menambahkan telur ke dalam adonan mi. Kadar abu mi basah yang dihasilkan berkisar antara 1,04-1,36\%. Angka ini masih masuk dalam persyaratan SNI (2987-2015) yaitu maksimum 3\%. Kadar abu suatu bahan erat kaitannya dengan kandungan mineral bahan tersebut. Mineral yang terdapat dalam suatu bahan dapat merupakan dua macam garam, yaitu garam organik (misal asam mallat, asam oksalat, asetat dan pektat) dan garam anorganik (misal garam fosfat, karbonat, klorida, sulfat dan nitrat).

Tabel 3. Hasil pengujian kadar protein, kadar abu dan kadar air mi basah

\begin{tabular}{cccc}
\hline Perlakuan & Kadar protein & Kadar abu & Kadar air \\
\hline A & $7,72 \%$ & $1,05 \%$ & $50,60 \%$ \\
B & $6,37 \%$ & $1,36 \%$ & $52,27 \%$ \\
C & $6,35 \%$ & $1,04 \%$ & $55,64 \%$ \\
D & $6,43 \%$ & $1,24 \%$ & $54,48 \%$ \\
E & $6,18 \%$ & $1,18 \%$ & $51,86 \%$ \\
\hline
\end{tabular}

Keterangan:: $\mathrm{A}=$ direndam larutan asap cair $0 \%$; $\mathrm{B}=$ direndam larutan asap cair $0,5 \%$; $\mathrm{C}=$ direndam larutan asap cair $1 \%$; $D=$ direndam larutan asap cair $1,5 \%$; $E=$ direndam larutan asap cair $2 \%$

Sedangkan kadar air mi basah yang dihasilkan berkisar antara 50,60$55,64 \%$. Kadar air ini masih memenuhi persyaratan SNI (2987-2015) yang menyebutkan bahwa mi basah matang (sudah direbus sebelum dikemas) harus mengandung kadar air maksimal 65\%. Mi basah dibedakan dengan $\mathrm{mi}$ jenis lain berdasarkan kadar air dan tingkat pemasakan awalnya. Mi mentah yang belum direbus mengandung air sekitar $35 \%$, mi basah (mi mentah yang direbus) mengandung air sekitar 52\%, mi kering (mi mentah yang dikeringkan) sekitar $10 \%$, mi instan (mi mentah yang dikukus kemudian digoreng) sekitar $8 \%$, sedangkan mi goreng (mi mentah yang digoreng) mengandung lipid sekitar $20 \%{ }^{(11)}$.

\section{Jumlah Pertumbuhan Total Mikroba}

Jumlah mikroba yang terdapat pada mi basah selama masa penyimpanan dapat dilihat pada Gambar 1. Pada hari ke-1, jumlah total mikroba berkisar antara $7,5 \times 10^{1}$ cfu sampai $3,18 \times 10^{2} \mathrm{cfu}$, dengan jumlah tertinggi pada perlakuan D. Namun pada hari ke-7, jumlah total mikroba mi basah pada semua perlakuan turun drastis sampai kisaran $1,66 \times 10^{1}$ cfu sampai $3,41 \times 10^{1} \mathrm{cfu}$. 
Hal ini menunjukkan bahwa perlakuan penambahan asap cair dapat mencegah pertumbuhan bakteri yang dapat menurunkan kualitas mi. Perlakuan D yang pada hari ke-1 mempunyai jumlah mikroba tertinggi, pada hari ke-7 justru mempunyai jumlah mikroba terendah. Pada hari ke-14 jumlah total mikroba tidak meningkat dan pada hari terakhir pengamatan yaitu hari ke-
21 , hanya perlakuan $B$ yang memperlihatkan kenaikan jumlah total mikroba. Sampai hari ke-21, jumlah total mikroba dari semua perlakuan masih berada di bawah jumlah maksimum yang diijinkan oleh SNI (2987$2015)^{(10)}$ yaitu maksimum $1,0 \times 10^{6} \mathrm{cfu}$. Hal ini menunjukkan, jika dilihat dari total mikroba maka mi basah yang disimpan selama 21 hari masih memenuhi persyaratan.

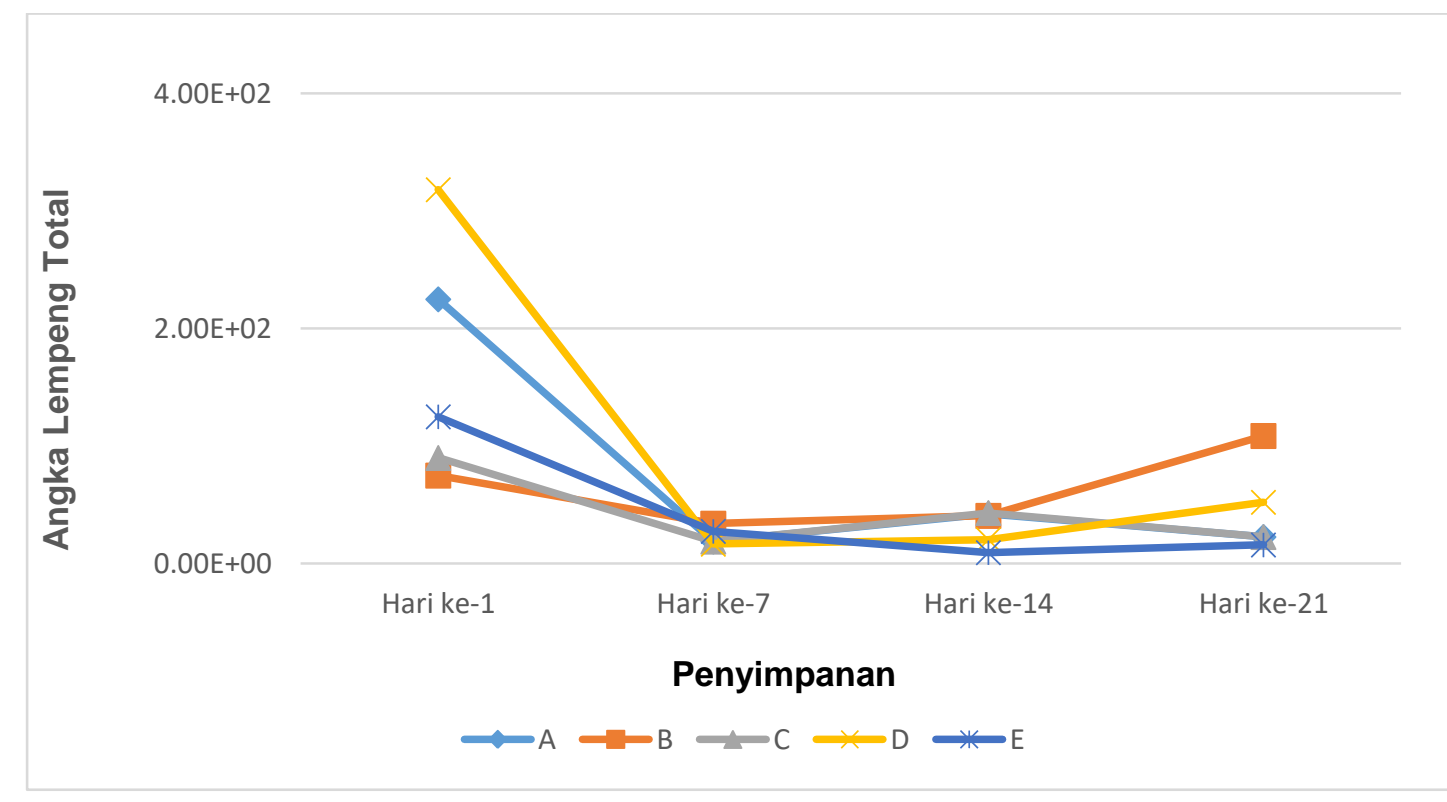

Gambar 1. Grafik pertumbuhan total mikroba pada mi basah selama penyimpanan 21 hari di suhu 5 ${ }^{\circ} \mathrm{C}$

Asap cair yang diperoleh dari proses pirosis memiliki kemampuan untuk mengawetkan bahan makanan karena adanya senyawa asam fenolat dan karbonil $^{(12)}$. Golongan fenol mampu merusak membran sel, menginaktifkan enzim dan mendenaturasi protein sehingga dinding sel mengalami kerusakan karena penurunan permeabilitas. Perubahan permeabilitas membran sitoplasma memungkinkan terganggunya transortasi ion-ion organik yang penting ke dalam sel sehingga berakibat terhambatnya pertumbuhan bahkan hingga kematian sel $^{(13)}$. Dalam konsentrasi tinggi, kandungan fenol menembus dan mengganggu dinding sel bakteri dan mempresipitasi protein dalam sel bakteri. Dalam konsentrasi yang lebih rendah, fenol menginaktifkan sistem enzim penting dalam sel bakteri ${ }^{(14)}$. Kemampuan senyawa fenol yang berperan sebagai zat antioksidan untuk menggantikan fungsi formalin sebagai pengawet bahan pangan yang berbahaya bagi kesehatan ${ }^{(15)}$.

\section{Pertumbuhan Kapang}

Pada Gambar 2 dapat dilihat jumlah kapang yang tumbuh selama masa 
penyimpanan 21 hari. Pada hari ke-1, jumlah kapang masih sangat kecil yaitu kurang dari 10 koloni/g mi basah. Perlakuan D mempunyai jumlah kapang tertinggi yaitu $3,0 \times 10^{1} \mathrm{cfu}$. Setelah penyimpanan selama 7 hari, jumlah kapang yang tumbuh meningkat dikisaran $3,17 \times 10^{1}$ cfu sampai $4,99 \times 10^{1} \mathrm{cfu}$. Pertumbuhan kapang paling tinggi pada penyimpanan hari ke-14 yaitu dikisaran $5,91 \times 10^{1}$ cfu sampai $1,36 \times 10^{1}$ cfu untuk kemudian turun di penyimpanan hari ke-21.
Di akhir masa penyimpanan 21 hari, jumlah kapang yang teramati paling banyak pada perlakuan A yaitu $2,55 \times 10^{1} \mathrm{cfu}$. Sampai hari ke-21, jumlah kapang yang tumbuh dari semua perlakuan masih berada dibawah jumlah maksimum yang diijinkan oleh SNI $(2897-2015)^{(10)}$ yaitu maksimum $1,0 \times 10^{4} \mathrm{cfu}$. Hal ini menunjukkan, jika dilihat dari kapang yang tumbuh maka mi basah yang disimpan selama 21 hari masih memenuhi persyaratan.

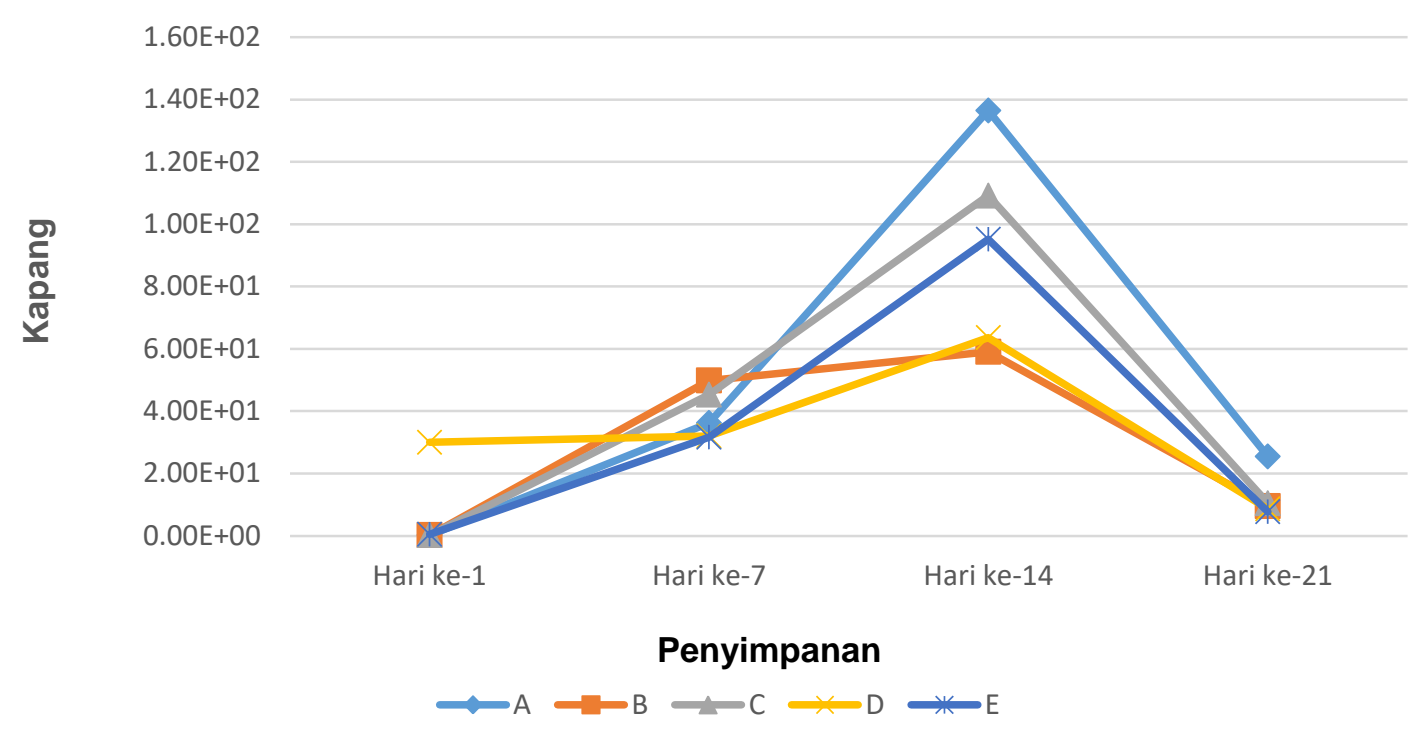

Gambar 2. Grafik pertumbuhan kapang pada mi basah selama penyimpanan 21 hari di suhu $5{ }^{\circ} \mathrm{C}$

Asap cair dari sabut dan tempurung kelapa mempunyai kelebihan dalam menghambat pertumbuhan bakteri pembusuk dan patogen. Kandungan asam yang cukup tinggi terutama asam asetat bekerja sebagai antimikrobia ${ }^{(16)}$. Selain itu memiliki kemampuan menghambat pertumbuhan jamur dan oksidasi lemak ${ }^{(9)}$.

\section{KESIMPULAN}

Soda abu yang diperoleh dari tungku kopra asap dapat ditambahkan ke adonan mi basah untuk menghasilkan mi yang bertekstur kenyal. Jumlah soda abu yang ditambahkan sebaiknya tidak melebihi $4^{\circ}$ Baume karena dapat menimbulkan rasa pahit. Penambahan asap cair ke dalam mi basah dapat memperpanjang masa simpan mi basah. Mi basah yang diberi tambahan asap cair, setelah penyimpanan 21 hari jumlah ALT dan kapangnya masih memenuhi persyaratan SNI mi basah. Jumlah asap cair yang ditambahkan tidak melebihi 
1\% karena akan menyebabkan mi basah

UCAPAN TERIMA KASIH

Ucapan terima kasih yang sebesarbesarnya diberikan kepada Ibu Fetty Indriaty atas bimbingan dan dukungannya sehingga penelitian ini dapat terlaksana dengan baik.

\section{DAFTAR PUSTAKA}

1. Hendinik B. Pembuatan Soda Kie dari Abu Kulit Buah Randu. 2011.

2. Yuniarti N, Sulhadi, Darsono T. Pemanfaatan Abu Kulit Buah Kapuk Randu sebagai Alternatif Bahan Pengembang Kue. In: Prosiding Seminar Nasional Fisika (EJournal). 2017. p. SNF 2017-MPS-99-104.

3. Polii FF. Pemanfaatan Abu Pembakaran Sabut Kelapa Pada Proses Pengasapan Kopra Menjadi Soda Abu sebagai Bahan Tambahan Makanan. Balai Industri Pertanian Sulawesi Utara. Manado, 2003.

4. Firdaus RA, Utami R, Nurhartadi E. Aplikasi Ekstrak Abu Sabut Kelapa sebagai Bahan Pengenyal dan Pengawet Alami dalam Pembuatan Mie Basah. Jurnal Teknologi Hasil Pertanian, 2015, 8.2.

5. Purnawijayanti HA. Mi Sehat. Kanisius, 2009.

6. Polii FF, Walangitan $\mathrm{A}$, Lumingkewas $\mathrm{M}$, Tora L, Adam P, Manoppo C, Siden AR. Pemanfaatan Limbah Abu Pembakaran Sabut Kelapa sebagai Bahan Tambahan Makanan. Komunikasi No. 315. Balai Riset dan Standardisasi: Manado. 2010.

7. Astawan M. Membuat Mi dan Bihun. Niaga Swadaya, 2000.

8. Yunus M. Teknologi Pembuatan Asap Cair dari Tempurung Kelapa sebagai Pengawet Makanan. Jurnal Sains dan Inovasi. Hal: 5361. 2011.

9. Darmadji P. Potensi Pencoklatan dari FraksiFraksi Asap Cair. Laporan Penelitian Dosen. Universitas Gadjah Mada. Yogyakarta. 1999.

10. SNI 2987:2015. Mi Basah. Badan Standardisasi Nasional. 2015.

11. Kruger et.al. Pasta and Noodle Technology. USA: American. 1999.

12. Wijaya ME, Noor T, Irawadi T, Pari G. Karakterisasi Asap Cair dan Pemanfaatannya sebagai Biopestisida. Bionature, Vol 9 (1): 30 40. ISSN1411-4720. 2008.

13. Damayanti E, Suparjana TB. Efek Penghambatan Beberapa Fraksi Ekstrak Buah Mengkudu terhadap Shigella Dysenteriae. Prosiding Seminar Nasional Teknik Kimia Kejuangan. Fakultas Biologi Universitas Jenderal Soedirman. Yogyakarta: 30 Januari 2007. berbau asap cair kuat.

14. Oliver SP, Gillespie BE, Lewis MJ, Ivey SJ, Almeida RA, Luther DA, Johnson DL, Lamar KC, Moorehead HD, Dowlen HH. Efficacy of a new premilking teat disinfectant containing a phenolic combination for prevention of mastitis. J Dairy Sci. 84: 1545:1549. 2001.

15. Solichin, M. Gema Industri Kecil Standard Teknologi Asap Cair "Deorub" menjadi Lokomotif Industri. Jakarta: Direktorat Industri Kecil dan Menengah. 2008

16. Darmadji P. Aktivitas Antibakteri Asap Cair Yang Yang Diproduksi dari Bermacam-Macam Limbah Pertanian. Agritech 16 (4): 19-22. 1996. 